\title{
On Becoming Creatures: Being Called to Presence in a Distracted World
}

\section{Brian Brock ${ }^{1}$}

As iconographer of our contemporary unease, the street artist Banksy puts his finger on the deep wounds of the modern westerner: the incapacity to live as creatures. His painting 'Mobile Lovers' in Clement Street, Bristol, for instance, depicts the embrace of a smartly dressed couple one dark evening. Her looking up to his face and him down to hers, both look blissful and strangely luminous. The sting of the image is that their faces are illuminated by the smart phones each surreptitiously checks over their partner's shoulder. The embrace encapsulates the peculiar distance and intimacy that has become such a striking characteristic of our present-it is a form of lived estrangement we recognize. This sensation of estrangement invites us to think again about the Christian doctrine of creation. What it is about our present that makes it so hard to be where we are? And how does the Christian confession of God as the creator of Heaven and Earth 'bring us back to earth'recreating us, with all our limits, in all our fullness as creatures?

In the course of the paper I will explain why in Christian theology these are questions that immediately draw in further questions about how we are to understand Jesus Christ as both the origin and end of creation as well as the one who is simultaneously tangibly present and yet 'not here'. It will require giving an answer to all these questions at once if we are to gain any purchase on what it might mean actually to live the Christian confession of God as Creator. Learning to live as creatures is a task that confronts every generation, but in this time after the fall it is one that each generation must approach having been positioned by traditions that assume the question is practically irrelevant. I will suggest that it is because we must learn to live as creatures, and not just think our creaturely status, that we must engage a range of theological doctrines simultaneously in any attempt to articulate what it means for we human beings to be creatures. The task is to find a way beyond, on one hand, the deism that claims that creatureliness for humans entails recognizing that God has equipped us with, and also left us to, our capacities to work with the world God has left us. On the other hand, the rival progressivism assumes, God is not entirely absent and can be plainly seen in every 'historical' moral breakthrough, taken to be signs of God perfecting a

\footnotetext{
${ }^{1}$ Many thanks to Don Wood and Ross Halbach for their very helpful comments on earlier drafts of this paper.
} 
creation made immature. Taught by the reformations traditions to attend to the centrality of God's speaking in establishing the redeemed life of God's chosen people in the biblical traditions, this paper asks about the human creature who lives in the certainty that God is neither mute nor reducible to complete transcendence or immanence, but speaks articulately to claim human beings for a living relationship. To be a creature is to have been gifted through the Spirit with a 'formed readiness' ${ }^{2}$ to God's speech which confronts and so breaks the hold of the roving desires and cultural distractions which have today become so widespread. The question is how.

I will enter this complex of questions through engagement with the works of Eric Santner and Dietrich Bonhoeffer. Santner's work turns on an incisive reading of Franz Rosenzweig's corpus, which will suggest overlaps in remarkable ways with central themes of Bonhoeffer's Creation and Fall. Though I will not be offering in this paper an account of their historical relationship (and their no doubt is a distant relationship ${ }^{3}$ ), I will contend that highlighting important convergences between Rosenzweig and Bonhoeffer can go some way toward helping us understand what it means to live the Christian confession of Jesus Christ as the origin and end of creation who Christians can trust to become present, and to make them genuinely present to the creaturely realm even in our late-modern developed-world context.

Banksy's diagnosis of our contemporary alienation in this case also localizes the complaint: our technologies have been configured to capture our attention in particularly irresistible

\footnotetext{
${ }^{2}$ Barth*

${ }^{3}$ Benjamin Lazier's God Interrupted: Heresy and the European Imagination between the World Wars (Princeton: Princeton University Press, 2008) maps the deep impact of Barth's second edition of his Römerbrief on both Jewish and Christian thinking in the interwar years. His treatment is especially relevant here in focusing on how debates about the God's transcendence and/or immanence and/or absence were the forum in which very different types of thinkers tried to come to terms with the constant strains and tearing of the European cultural fabric that characterized the nineteenth century. See also Samuel Moyn, Origins of the Other: Emmanuel Levinas between Revelation and Ethics (Ithaca: Cornell University Press, 2005), esp. ch. 4. A comment made by Leo Strauss in 1970 gives us a measure of the importance of the background discussions in which both Rosenzweig and Bonhoeffer's work must be understood: "The preface to the first edition of [Barth's] commentary on the Epistle to the Romans is of great importance also to nontheologians: it sets forth the principles of an interpretation that is concerned exclusively with the subject matter as distinguished from historical interpretation. Wholly independently of Barth, Jewish Theology was resurrected from a deep slumber by Franz Rosenzweig, I highly gifted man whom I greatly admired to the extent that I understood him." (Quoted in Lazier, 93.) Though Lazier refutes Strauss' claim that Rosenzweig's thinking can be so easily dissociated from the impact of Barth, his work also indicates how rich the cross fertilization was and why Christians do well to listen to Jewish responses to, and inflections of, post-Barthian theology, as I attempt to do in this paper, taught by more recent Christian thinking on this topic, supremely Tommy Givens, We the people: Israel and the Catholicity of Jesus (Minneapolis: Fortress Press, 2014).
} 
ways. We know all too well that the sound of an arriving text or e-mail can involuntarily drag our thoughts away from a conversation or interrupt a train of thought. This offers to some a solution-why not then resolve our situation by getting rid of or turning off our distracting devices?

In his Novel Microserfs ${ }^{4}$ Douglas Coupland suggests some of the reasons why we will need to go deeper in order to come to terms with what it might take to make us present to one another, to cure our temptation mentally to wander away from what is before us. He tells a modern day love story, a meeting at Microsoft headquarters, a quest for a more lively life than they can see at the corporate giant and then a move together to work for a startup in Silicon Valley. The novel is filled with nuanced depictions not only of the manifold cultural forces that thwart our desires to just 'give up' our distraction but also on the reasons why these forces are so irresistible to us. We may chafe at our lifeness existence, but we cannot just renounce it, and so we replace it with new routines that promise liberation but soon become just as denuding. We need other persons to speak our names in love if this treadmill of deadening routine is to be broken, rendering us people who can truly become present in the material world.

In the past decades theologians and ethicists have often emphasized that theological language, especially technical and confessional language, needs specification through examples or narratives if it is to be intelligible to readers in precise and at the same time extensible ways. ${ }^{5}$ This is an important development, one with which I am in strong sympathy, especially the emphasis it embodies of close attention to the interface of more technical theological language and everyday language use. In this paper I will use the footnotes to pursue a skewed version of this convention, citing passages from Microserfs in the footnotes that strongly converge with the main themes under discussion on the body of the paper. Like the theological thinkers of the interwar years who are the focus of this paper, Coupland both acutely feels the hollowness of the late modern North American middle classes and has an uncanny ear for the verbal rhythms which strain to articulate that hollowness as well as locating the points at which it might not be disappointing to hope for new life to emerge. In finding language to describe the world as we know it today, Coupland

\footnotetext{
${ }^{4}$ Douglas Coupland, Microserfs (London: Harper Perennial, 2004).

${ }^{5}$ Hauerwas on narrative in ethics*
} 
thus articulates features of inhabitants of the developed world who are simultaneously excited by progress and frightened by the upheavals and insecurity that attend it $-a$ configuration that Rosenzweig and Bonhoeffer explicated many decades before. My interest in Coupland, then, is not so much in the narrative he offers, but in the language he finds to encapsulate the unique configurations of stories which emerge from our present. Like any good novelist, he is seeking the grammar of our present, by which modern human beings might begin to designate what counts as 'our story'. ${ }^{6}$

In the broadest terms, the problem is how theologically we should narrate this distraction, this inability to be where we are, this living death. The answers we will give to this question are intertwined with how we conceive of its overcoming or redemption. It is a problem as least as old as the letters of St. Paul. Consider this train of thought from Colossians:

'He is the image of the invisible God, the firstborn of all creation; for in him all things in heaven and on earth were created...through him and for him. ... He is the head of the body, the church; he is the beginning, the firstborn from the dead, so that he might come to have first place in everything.' (vv. 1:15, 16, 18)

'...when you were buried with him in baptism, you were also raised with him through faith in the power of God, who raised him from the dead. And when you were dead in trespasses and the uncircumcision of your flesh, God made you alive together with him...' (2:12-13)

'So if you have been raised with Christ, seek the things that are above, where Christ is, seated at the right hand of God. Set your minds on things that are above, not on

\footnotetext{
${ }^{6}$ I have opened this paper by attending to the secular prophets of our age, who vividly render the problems with which I am concerned in this paper. A more traditional introduction would have pointed out that the most influential free thinkers of early modernity charged Christianity with being an otherworldly religion in order to incorporate the two most widespread accusations: that Christianity evaded the problem of evil and that even Christians could not live up to their own morality. In the wake of this criticism some thinkers, such as Ludwig Feuerbach and Sigmund Freud, re-read Christianity as a projection of human moral aspiration. Others, such as Charles Darwin (now repeated in bowdlerized form by Richard Dawkins et. al.) invited humanity to embrace the realization that humans are no more transcendent than any other animals and live in a universe that, if it was created by God, is now left to its own devices. Thinkers such as Adam Smith and Karl Marx predicted the world this trajectory would produce, in which the negotiation of human desire would be the central political and intellectual task of a thoroughly immanantized western cultural space. This paper will suggest that the restlessness of modern desire that has become so characteristic of our age fuels the most intractable public moral debates today as well as sustaining acutely painful forms of alienation in interpersonal and familial relationships. It is, in short, the form our fallen estrangement takes today. This paper lays important groundwork for a response to those theologians today who see the problem as just set out, but who seek to redirect and chasten the roving desiring that animates modern western societies rather than questioning its having been established as the basis of our common life in the first place (such as Charles Matthewes, * ch. ).
} 
things that are on earth, for you have died, and your life is hidden with Christ in God.' (3:1-3)

'Do not lie to one another, seeing that you have stripped off the old self with its practices and have clothed yourselves with the new self, which is being renewed in knowledge according to the image of its creator.' (3:9-10)

Paul has already suggested a set of linkages that will be essential for any genuinely Christian answer to the problem of lived estrangement and in doing so has indicated that the doctrine of creation will play a central role in this answer. He does not approach the theme of creation directly, but through the work of Christ, and more precisely, through the enlivening of the individual believer in Christ. Thus his account of creation comes alive in the tensions between several theological affirmations: between the imago Dei and Jesus Christ, who is also the origin and end of creation; between the ascended Christ who draws the gaze of the Christian above immanent affairs and who somehow holds our true and redeemed form to himself; he associates this new form with the practices of this life and through their being changed (by mechanisms unspecified), our self that is hidden in Christ is being transformed to image the creator. I take Paul's approach to the doctrine to be both informative and exemplary for the Christian theologian in that he does not set out definitions of these doctrinal themes in a discreet and sequential fashion, but shows or displays how the terms cohere as a constellation of language, language which he performs as a Christian, and as an apostle, and as a writer. This performance displays why something crucial is lost if the hermeneutical and intertextual texture of theology is extracted from analysis of Christian moral existence. On my reading Bonhoeffer not only approaches theology in this manner but his Creation and Fall should be read as an extended exploration of the thematic unity of the same constellation of doctrinal themes we see set out by Paul.

Paul thus reminds us that in the New Testament the question of creation is bound up with problems related to the relation of the 'hereness' to the 'not hereness' of Jesus Christ to creatures that are a necessary entailment of a Christian confession of Jesus Christ as Son and the Father as creator. But how do they relate? On the surface the rejoinder to 'set our mind on things above' seems calculated to exacerbate our dissasifaction with our places and lives as they are. The problem is not confined to Christians, and has also exercised modern Jews and in an inverted form, non-believers: in the face of the silence and/or death of God, 
how can human action not simply devolve into existentialist willing which can give no reason to take givenness and proximity seriously? ${ }^{7}$

The biblical creation story suggests that humans are creatures that, after the fall, are both displaced from the place given to them in creation in which they were truly at home and as a result, in their fallen state, they are caught in the routines of their flight-centripetal and dissatisfied creatures uneasy with themselves and their limits. In his book On the Psychotheology of Everyday Life ${ }^{8}$ Eric Santner presents Franz Rosenzweig's incisive account of the chronic living death of modern life, that is characterized by an animate but nevertheless sterile experience of loss, a loss which it does not have the power to cure. Santner also finds in Rosenzweig a promise of messianic exodus from the manias that simultaneously support and numbingly constrain our lives. To become present to 'place' is, for Rosenzweig to have undergone the 'undeadening' intervention of another person, who offers us an exit route in the midst of the tangle of our lived lives. After explicating Santner's case, I will turn in a final discussion to show how the main lines of his analysis both parallel and offer is ways to sharpen important aspects of Dietrich Bonhoeffer's account in Creation and Fall of the dynamics of the fall and the healing of creatures. This latter account will clarify why coming to terms with our creaturely 'thereness' is by no means in incidental aspect of a Christian gospel that can speak to a world saturated by the desire to be elsewhere. Bonhoeffer will suggest, in tones that echo Rosenzweig, that what we need to narrate is our re-integration into life with the Creator that alone made Eden a home for the first humans.

\section{The call of another as exodus from internal captivity: Santner and Rosenzweig}

Consider Robert Waltzer's short story about the child who sets out to walk to the edge of the world, Santner begins. The child will discover in time what we already know: the edge of the world is not accessible in this way. Despite the impossibility of the quest, the story nevertheless ends happily when the child finds a house called 'the end of the world' where she discovers that she can be 'at home' in the way she had never been before setting out on her journey. Reflecting on Waltzer's tale, Franz Kafka responded with his own, 'The Top',

\footnotetext{
${ }^{7}$ Lazier, God Interrupted, ch. 13

${ }^{8}$ Eric Santner, On the Psychotheology of Everyday Life: Reflections of Freud and Rosenzweig (Chicago: University of Chicago Press, 2001).
} 
depicting a philosopher obsessed, not with the limits of the outer world, but its animating order. If only he could grasp the playing childrens' top mid-rotation, he believed, he would glimpse the key to universal truth. Both tales study the compulsions that bar humans from inhabiting the midst of life, compulsions crying out for interruption. An exodus is needed from our captivity to the idea that we need to be somewhere else, 'not one from ordinary life into a space beyond it, but [an exodus that is] just the opposite: a release from the fantasies that keep us in the thrall of some sort of exceptional "beyond"'. ${ }^{9}$ Santner labels this condition 'Egyptomania', making reference to the dynamic that plagued the ancient children of Israel: though in captivity, they loved and came to think their lives wholly within its strictures, as revealed by their feelings of longing for it after their physical liberation. The insight is powerful in recognizing that our most determinative forms of captivity in the modern world are not ones sustained by external constraint: the decisive liberation we need is from the captivity of our minds and desires to the schemas of the age.

In his Understanding the Sick and the Healthy: A View of World, Man and God, Franz Rosenzweig ventured a hypothesis about this entrapment and the means of liberation from it. Here it is not the novelist but a novelistic portrait of the philosopher who serves as the exemplary case. Extending the tales of Waltzer and Kafka, this philosopher becomes addicted to a moment of wonder. Rosenzweig insists that wonder is something that befalls everyone and that should draw every human being into the flow of everyday life. We wonder at the birth of a child, for instance, but this wonder properly energizes and so is dissipated into the day to day life as a parent. This incorporation Rosenzweig calls living in the 'heart of wonder'. Impatient of this temporally unfolding passage of wonder the philosopher, star struck by wonder, becomes obsessed with what it 'really' is. This is the pitfall.

A thing receives a character of its own only within the flow of life. The question, "what is this actually?", detached from time, deprived of it, quickly passes through the intermediate stage of the general term and comes into the pale region of the mere "thing" [des Dinges überhaupt]. Thus emerges the concept of the one and only substance, the "essential" nature of things. The singleness and particularity of the

\footnotetext{
${ }^{9}$ Santner, On the Psychotheology of Everyday Life, pp. 30-31.
} 
subject [Eigenheit des Gegenstandes] detatched from time is transformed into a statement of its particular essence [Eigentlichkeit des Wesens]. ${ }^{10}$

In modernity, Rosenzweig suggests, this is not a disease that afflicts only professional philosophers but has become widespread, indeed, had become the socialized norm of modern industrial societies. These defenses are attractive in seeming to promise a way around death by offering a means of grasping and in some sense touching that which endures. But it is this stalling in wonder which is itself 'the paralysis of artificial death'paralyzed because stuck in the excess of moments of wonder, and dead because this very stuckness bars us from incorporating wonder as the lively impeller of our everyday existence. Thus it is a habit of mind that increasingly estranges us from finding our way into the 'heart of wonder' because trapping us in modes of perception that become a type of defense against the changes that sustain lived life. ${ }^{11}$

Santner is attracted to Kafka, whom he pairs with Sigmund Freud, as an analyst of the laws (both literal and social) that have become social diktats with force but without significance. It is these routines without meaning, this obedience to the laws of capital and fashion and global politics that produce and sustain our deadening activity, in which we do not really believe, but from which no obvious escape is on offer. ${ }^{12}$ What needs to be suspended in order to break this deadening cycle is our enjoyment of it, which, paradoxically, lives in our imaginations and planning but which nevertheless sustains our active paralysis. The incursion of messianic time that we need to release us from this static motion, 'ought then

\footnotetext{
${ }^{10}$ Quoted in Santner, On the Psychotheology of Everyday Life, 21.

${ }^{11}$ One character in Microserfs describes himself as one of the "dreamless children, alive but not living," ( $p$. 371), and Coupland has his main character reflect, "I got to thinking of my cramped, love-starved sensationless existence at Microsoft-and I got so pissed off. And now I just want to forget the whole business and get on with living - with being alive. I want to forget the way my body was ignored, year in, year out, in the pursuit of code, in the pursuit of somebody else's abstraction. [...] Maybe if this thing with Karla hadn't started I never even would have noticed-l'd have accepted my sensory-deprivation lifestyle without a second thought. She's helping me get closer to getting a life-and having a . . personality." Microserfs, pp. 90-91.

12 "Susan says the Gap is smart because they cut it both ways: "Kids in Armpit, Nebraska, go into a Gap with pictures in their heads of Manhattan, Claudia Schiffer, and the Concorde, while kids in Manhattan go into the Gap with a picture in their head of Armpit, Nebraska. So its as though Gap clothing puts you anywhere except where you actually are." [...] We also figured that Gap clothing isn't just about place, nor is it about time, either. Not only does Gap clothing allow you to look like you're from nowhere in particular, it also allows you to look as though you're not particularly from the present either. "Just look at the recent 'Khakis of the Dead' campaign," says Bug. "By using Balanchine and Andy Warhol and all these dead people to hustle khakis, the Gap permits Gap wearer to dissociate from the now and enter a nebulous then, wherever one wants then to be in one's head . . . this big place that stretches from Picasso's '20's to the hippie '60's."'” Microserfs, pp. 268269.
} 
to be thought not so much in terms of a reanimation of the dead-the conventional understanding of the advent of the Kingdom - as of a deanimation of the undead' ${ }^{13}$ With this paradoxical formulation Santner indicates human activity that continues to be organized by an idea that the agent has rejected, but that nevertheless is characterized by a sense of nameless loss that remains compelling.

When, for example, one has lost the capacity to pray, "God," in essence, assumes the status of a designated signifier, a stand-in for an otherwise nameless loss; the word signifies, but not for us even though we continue, in some sense, to be addressed by it, to live, as Scholem so powerfully phrased it, within the space of its validity beyond and in excess of its meaning. Against this background, the claim that "God is dead" comes really as something of a relief-a "gentrification" of catastrophe-in that it effectuates a conversion far more disturbing, because nameless, loss into something we can mourn. ... If there is a "Jewish" dimension to psychoanalytic thought, it is this: the cure is indeed a kind of "exodus," only not one out of Egypt; it offers, rather, an exodus out of the various forms of Etyptomania that so profoundly constrain our lives and, while sustaining a level of adaptation, keep us from opening to the midst of life. ${ }^{14}$

Santner is situating Rosenzweig's messianism as an extended philosophical exploration of how our imaginations and mental energies can be unplugged from the apparent necessities and laws of the social-political-symbolic order of our day. ${ }^{15}$ This unplugging can neither be accomplished by thought nor simply by changing habits. Release comes only through the claim of another breaking in on us. The deanimation of our undeadness thus demands revelation. This is so, Santner continues, because the key to Rosenzweig's thought is a distinction between two forms of interpolation. What Santner calls 'symbolic investiture' is an interpolation which trains the subject to identify themselves as members of a larger

\footnotetext{
${ }^{13}$ Santner, On the Psychotheology of Everyday Life, p. 44.

${ }^{14}$ Santner, On the Psychotheology of Everyday Life, pp. 44-45. "I really have to wonder if Todd's dong steroids. I mean, he just not physically normal. We're all going to have to face this. [...] I asked Todd, "Shit, Todd-what is it exactly you want your body to do for you? What is it your body's not doing for you now that it's going to do for you at some future date?" Not really Todd's sort of question. "I think I want to have sex using a new body which allows me not to have to remember my ultrareligious family." Todd mulled this over. We looked around the apartment, strewn with hex dumbbells and rubber flooring mats. "My body was just something I could believe in because there was nothing else around."” Microserfs, p. 244.

${ }^{15}$ It is, at the same time, a rejoinder to Barth, who Rosenzweig thought set God too ineffably and transcendently over the world. See Moyne, Origins of the Other, pp. 158-161.
} 
social or political whole. This is an operation continually taking place in order to sustain the domain of general and public rationality. The call of love, in contrast, singles us out, claiming us particularly, and so demanding we identify ourselves differently than we are asked to do within the general domain of the public. Such a call momentarily suspends the performative utterances that normally invest us with intelligible social identities ('symbolic investiture'), but in so doing situate us as parts of a larger whole, cogs in the meaningless movement of production and exchange. It is this revelatory investiture which for Rosenzweig makes it possible, 'to convert a rigidity at the very core of one's being-[tone* check] that enjoys the double valence of "stuckeness" and "animation" into a resource of transformation.'16

In his famous and famously difficult Star of Redemption Rosenzweig explicates this messianic revelation that releases human beings from their living deadness as the passionate calling of one's proper name. What Santner calls Rosenzweig's psychotheological point is that so long as love itself, including the love of God, is understood in terms of a generic relationship, a giving one's self into an extant relation, God along with all other beings can only remain one of many entities continually looping us into the generic socialsymbolic order. ${ }^{17}$ This God remains one signifier in the universal law standing over us and thus can only be discussed in the third person (Rosenzweig has Spinoza's God in mind here).

\footnotetext{
${ }^{16}$ Santner, On the Psychotheology of Everyday Life, p. 65.

${ }^{17}$ Coupland has the post-believing steroid user articulate his liberation thus: "Nobody's every spoken to me before. I mean, not to me. I was always just a soul to be harvested [evangelized] or a human unit." Microserfs, p. 241. Elsewhere another character articulates the problem of experiencing one's self as a "human unit", which Santner has called the problem of "symbolic investiture" - as well as how the calling of our name releases us from it.
}

Before bed I told Karla about Ethan's identity holiday_of drinking to recapture the feeling of what your real personality used to feel like.

"It's all about identity," she said.

She said, "we look at a flock of birds and we think one bird is the same as any other bird-a bird unit. But a bird looks at thousands of people, at a Giants game up at Candlestick Park, say, and all they see is "people units." We're all as identical to them as they are to us. So what makes you different from me? Him from you? Them from her? What makes any one person any different from any other? Where does your individuality end and your species-hood begin? As always, it's a big question on my mind. You have to remember that most of us who've moved to Silicon Valley, we don't have the traditional identity-donating structures like other places in the world have: religion, politics, cohesive family structure, roots, a sense of history or other prescribed belief systems that take the onus off individuals having to figure out who they are. You're just on your own here. It's a big task, but just look at the flood of ideas that emerges from the plastic!"

I stared at her, and I imagine she was assuming I was digesting-compiling-what she'd just told me, but instead, all I could think of, looking into her eyes, was that there was this entity-Karlawho was different from all others I knew because just under the surface of her skin lay the essence of herself, the person who thinks and dreams these things she tells to me and only me. I felt like a lucky loser and I kissed her on the nose. Microserfs, p. 236. 
Such deadening loops are only broken when we experience the infinite difference between a relation and an encounter, between love that is the basis of our being, our knowable 'essence', and the revelatory love of an eventful encounter with someone who calls our name in love. We humans can only call another's name out of our own death-driven singularity. Thus not only other human beings but God as well, when calling our names, inevitably expose our death-driven singularity. ${ }^{18}$ The crucial point, Santner suggests, 'is that revelatory love is addressed not, as Rosenzweig writes, to my "brother in forest and grove, in rock and water," but rather to what is most characteristic of the Other: the always contingent, singular, and, in some since, "demonic" way in which he or she contracts a foothold in Being. ${ }^{\prime 19}$ God's revelatory encounter can only function, insists Rosenzweig, if it penetrates my inner darkness, my unfreedom which is the form my exercise of freedom has taken. The ' $I$ ' that needs to be named in order to liberate us from our deadness, is the resistant I, the truculent and misshapen I who resists bowing to the laws of truth and rationality. ${ }^{20}$ This ' $l$ ' is most us, paradoxically, because it reveals nothing beyond the testimony of our willed confusion and resistance with its own unique and contingent configuration. ${ }^{21}$

\footnotetext{
18 The ambiguous relation between human and divine love here is intentional, and Rosenzweig offer it under a verse from the Song of Songs (8:6) "Love is as strong as death." See Moyne, Origins of the Other, pp. 146-147. Rosenzweig's intention is to stress that it is with human words, spoken from human mouths, that God has chosen to reveal God's self-as we learn from the stories of the prophets, priests and kings recounted in scripture, and as we also learn from the form taken by scripture. See Robert Gibbs, Correlations in Rosenzweig and Levinas (Princeton: Princeton University Press, 1992), ch. 4.

${ }^{19}$ Santner, On the Psychotheology of Everyday Life, p. 89.

${ }^{20}$ Coupland describes how it is the resistance to this self by those closest to us which wounds us most deeply, shaping the fears and neuroses that organize our undeadness. "It turns out that Karla's parents always told her that she was stupid. Everything in life Karla had ever achieved-her degrees and her ability to work with numbers and code, had always been against a gradient of her parents saying, "now why'd you want to go filling your head with that kind of thing - that's for your brother Karl to do." "Karl's nice, and we like each other," Karla said, "but he's a total [IQ] 100-center of the bell curve and no way around it. My parents drove him crazy expecting him to be a particle physicist. All Karl wants to do is manage a Lucky Mart and watch football. They've always refused to see us as we are" (p. 99). Karla continues, discussing her anorexia, “"I didn't want to do what I was doing, Dan -it just happened. My body was the only way I could get my message across and it was such a bad message. I crashed myself. In the end, it was work that saved my life. But then work became my life-I was technically living but without a life. And I was so scared. I thought that work was all there was ever going to be. And oh, God, I was so mean to everybody. But I was just running so scared. My parents. They just won't accept what was going on with me. I see them and I want to starve. I can't let myself see them"”' (p. 101).

${ }^{21}$ By giving us reasons for this definition of estrangement Rosenzweig helps us to make sense of Bonhoeffer's (non-traditional) insistence that "every one of us is also the "first" sinner". Bonhoeffer, Creation and Fall, p. 115.
} 
Though Santner himself does not draw out the connections of this account of the liberation of the individual, it in fact rests on an account of Israel's election. ${ }^{22}$ Rosenzweig is in fact deducing the form he understands the love of neighbor properly to take from God's acts of loving. ${ }^{23}$ This is why Rosenzweig suggests that what is true of individuals is even more true of groups; here the Jewish people provide the paradigm case of the constitution of 'undead' humanity by way of God's call: 'There is no essence - that would be "concept" of Judaism. There is only a "Hear, O Israel".'24 This call not only means that Jewish life is played out outside the frame of a 'universal history', but that it also plays a specific unsettling role within that larger whole. The destiny of the Jews is neither historical (playing characters in the one story of humanity) nor ahistorical (being above the rhythms of publically acknowledged historical events) but meta-historical-Jewish history is always a history of the remnant of those 'called out' but who have inhabited and so taken up the histories of the times and places in which their elected lives have taken place. ${ }^{25}$

Again a close connection is being drawn by Rosenzweig between revelation and our most ignoble selves. One of the essential shocks of revelation is that it reveals our woundedness and our love for being stuck, our own particular form of deadening imagination and routine. It is hard to admit that we were once loveless. 'And yet-love would not be the moving, the gripping, the searing experience that it is if the moved, gripped, seared soul were not conscious of the fact that up to this moment it had not been moved nor gripped. Thus a shock [eine Erschütterung] was necessary before the self could become beloved soul. ${ }^{26}$ And with this shock domes an associated shame that we lived so long under the power of this deadening spell.

Revelatory love is thus the diametrical opposite of the relational surrender which only more deeply entraps us in the generic. The paradox, however, is that it forces upon us the choice between holding on to our means of escape from our present, or responding to the Other who calls our name. It is because love can only liberate us by exposing us as those who have

\footnotetext{
22 This basis is well documented in Richard A. Cohen, Elevations: The Height of the Good in Rosenzweig and Levinas (Chicago: University of Chicago Press, 1994), ch. 1.

${ }^{23}$ Moyne, Origins of the Other, p. 152.

${ }^{24}$ Quoted in Santner, On the Psychotheology of Everyday Life, p. 112.

${ }^{25}$ Susan Handelman, in Fragments of Redemption: Jewish Thought and Literary Theory in Benjamin, Scholem, and Levinas (Bloomington: Indiana University Press, 1991) helpfully explicates the reasons for this widespread attach on Hegelian accounts of history among Jewish-German philosophers between the two world wars.

${ }^{26}$ Quoted in Santner, On the Psychotheology of Everyday Life, p. 84. His emphasis.
} 
exercised our freedom in defiant paralysis that we experience the call of the other as a challenge. This is the necessary cost of exit from the logic of socio-symbolic relations into the logic of ethical encounter, which for Rosenzweig is, most decisively the messianic event of divine love. By this call the self is offered a foothold in being, an exodus from our Egyptomania, which the Judeo-Christian tradition has called the Kingdom. It is an opening up to the other at the very heart of life because opening us up passionately to what is singular about the other. 'Not out of his own essence and out of the purity of his own heart does he discover the other, but out of the happening which happed to him and the deafness of his heart. ${ }^{27}$ It is in this experience of our misshapen embodiments of freedom being called by name in love that the everyday which we have tried so hard to evade is rendered habitable.

Santner encapsulates his central point thus:

...the Kingdom, as I take Rosenzweig to understand it, is not about the reanimation of the dead - the passage to a realm beyond the one of our vulnerability and mortality-but concerns rather the deanimation of the undead (undeadness understood as the persistence of metaphysical lonliness). We enter the Kingdom not by transcending social relations but by intervening into and converting our mode of capture by social relations. The paradox Rosenzweig is getting at is that the very (unconscious) fantasies at work in this capture actually keep us at a kind of distance from life. Revelation is ultimately nothing but a clearing away of the fantasies that confine our energies within an ultimately defensive protocosmic existence-our various forms of "Egyptomaina" - that keep us at a distanced from our answerability within everyday life and...from the possibilities for new possibilities that are all the time breaking out within it. Again, the paradox is this: a certain fantasmatic distance is correlative to our psychic capture by existing social relations-to what I have referred to as our "relational surrender" - and thus to the foreclosure of the possibility of new possibilities that can only truly arise in the eventful space of encounter. ${ }^{28}$

\footnotetext{
${ }^{27}$ Quoted in Santner, On the Psychotheology of Everyday Life, p. 91

${ }^{28}$ Santner, On the Psychotheology of Everyday Life, p. 100-101.
} 
In short, Rosenzweig aims to deepen the internal connections between revelation, election and the law. When revelation is understood as the promulgation of an imperative to love the neighbor it is placed in a series alongside the whole range of legal-social-symbolic imperatives that govern our lives. But Rosenzweig insists that this is an inappropriate way to understand God's law. The person to whom the law is attached must reveal themselves, and must do so amidst the eccentricities and perversities that characterize our everyday mental worlds. Drawing an analogy with marriage, Rosenzweig compares the Torah to the marriage certificate. Though the daily and even hourly reality of the living relationship of the spouses is not publically narratable, it is nevertheless the reality of a living marriage, which is never reducible to that which can be proved by a marriage certificate. The objectively present legal document is thus a condition of a living marriage that only becomes real as it is lived into in the private rhythms of festive days and anniversaries. ${ }^{29}$

Rosenzweig's appeal to private life should not mislead us here; he is not pointing to the hiddenness of our life with those we love, and who love us, supremely God, but to the temporality of life together. Life in interpersonal communion that is not a deferral but a genuine shared temporality can never be adequately reduced to a generalized, 'conceptualized,' narration available to the whole public. This is true despite the fact that our intimate relationships are full of brokenness and obstinacies, which cannot be simply 'cleared out' without destroying the relationship. God's commandments, on this view, should be understood as the environment that sustain the living relationship between God and his people as a vital experience rather than allowing it to be translated into a thirdperson relationship, some set of generic 'rules for living'. 'The force of the commandments derive, in other words, not simply from the fact that they permeate the practices of everyday life (rather than present a series of principles or theological doctrines about man, God and the world), but also from the fact that they emphatically turn the one thereby engaged to everyday life and the Other who is there with us,' concludes Santner. 'In the life shaped by the commandments there is always this stranger in our midst ${ }^{\prime 30}$-the stranger in us who has irrationally enacted our freedom but who is nevertheless called out by name in love.

\footnotetext{
${ }^{29}$ Quoted in Santner, On the Psychotheology of Everyday Life, p. 119.

${ }^{30}$ Santner, On the Psychotheology of Everyday Life, p. 120
} 
Santner concludes by suggesting that this movement toward ethical encounter in everyday life depends on recognizing that the imperative to be open to the stranger is driven not by socio-political accounts of national status or locality, nor by a decreed moral demand understood in terms such as the categorical imperative, but by the Other who has revealed the 'monstrous' and 'demonic' stranger in myself who is sealed off in routines of escape from time and place. The celebration of the Sabbath is for Rosenzweig the "holiday from the everyday' that suspends the daily fantasies that burden our everyday life by constraining our capacities to hear and see the other. The celebration of the Sabbath can make a great difference in how human beings live their daily lives in focusing them on the power of human and divine speech to remake us, speech which is always idiomatic because always uttered in local times and spaces-freeing us to live in the heart of wonder. ${ }^{31}$

\section{The materiality of the other as site of the divine call: Bonhoeffer's Creation and Fall}

Bonhoeffer as we find him in Creation and Fall resonates with Rosenzweig and the Paul of Colossians in construing the primary work of the God of Jesus Christ as supremely concerned with establishing life and liveliness at the heart of the broken reality of concrete human existences. 'God does not will to be Lord of a dead, eternally unchangeable, subservient world, instead God wills to be Lord of life with its infinite variety of forms. ${ }^{32}$ For Bonhoeffer the boundary between sterile repetition and genuine liveliness is the resurrection of Jesus Christ understood as giving life through the act of divine speech. '[I]t is God's command which creates that which lives out of what is dead-it is God's being able to raise up children to Abraham out of these stones, and calling Christ to rise up from the dead earth. ${ }^{33}$

This emphasis on the reliance of creaturely life on God's own speaking explains, for Bonhoeffer, why it is not nonsense to refer to living things as dead. Living things can be dead in the way that Darwinian immanentism is dead: nothing in world occurrence is

\footnotetext{
31 "I called Mom from the hotel during this period of peace. I'd turned out all of the lights and closed the curtains in pursuit of sensory deprivation. It was black and sensationless. All there was in the room was my voice and Mom's voice trickling out of the phone's earpiece, and this feeling passed through me-this feeling of what a gift it is that people are able to speak to each other while they're alive. These casual conversations, this familiar voice heard through a Las Vegas hotel room telephone. It was strange to realize that, in one sense, all we are is our voice." Microserfs, pp. 353-354.

32 Bonhoeffer, Creation and Fall, p. 57.

${ }^{33}$ Bonhoeffer, Creation and Fall, p. 57.
} 
allowed to transcend the explanation that all that happens is caused by the force of material conditions. Only human lives that have been rescued from this particular form of routinized, hermetically sealed and meaningless motion can truly be called free. In creating humans God has not created little creators, but beings in his own likeness in the sense that they are not created to be ruled by the laws of their being; neither of nature nor historical sequence. Bonhoeffer is intentionally resisting the definition of freedom that has become dominant since the Enlightenment, in which freedom is understood as our unfettered choice free from the interference of others, and bounded only by other's freedoms. Freedom, as Bonhoeffer understands it, is never a quality humans possess, and is neither a skill nor a thing;

It is a relation and nothing else. To be more precise, freedom is a relation between two persons. Being free means "being-free-for-the-other" because I am bound to the other [Freisein heißt, "frei-sein-für-den-anderen", weil der andere mich an sich gebunden hat]. Only by being in relation with the other am I free. ${ }^{34}$

Again striking in its resonances with Rosenzweig's account, Bonhoeffer too understands freedom as an event that happens to me only with and through another person. For Bonhoeffer the grounds of this claim are essentially Christological: we can only know true freedom because Jesus Christ has been resurrected. Through a contingently specific incorporation into this particular resurrection human beings are drawn out of their fallen deadness. It is because he moves from this Christological starting point (here paralleling Paul's approach in Colossians) that Bonhoeffer can affirm that true creaturely freedom always appears as a paradox in a fallen world. Unfreedom appears rational and normal in such a world, which is why God must create free human beings. Only in the unique work of Jesus Christ is the grammar of God's freeing individual human beings to image the true creature, Jesus Christ, manifest. Because God is genuinely free for relationship, God has and continues to enter into creation to re-establish the human desire and capacity for that relationship. Thus, 'In the free creature the Holy Spirit worships the Creator; uncreated freedom glorifies itself in view of created freedom.' ${ }^{35}$ These opening moves prepare

\footnotetext{
34 "How can what is created be free? What is created is determined, bound by law, condition, not free. If the Creator wishes to create in the Creator's own image, then the Creator must create [the human] free. And only such an image, in its freedom, would fully praise God, would fully proclaim God's glory as Creator." Bonhoeffer, Creation and Fall, p. 63.

${ }^{35}$ Bonhoeffer, Creation and Fall, pp. 63-64.
} 
Bonhoeffer to emphasize why the work and claim of Jesus Christ ties us to creation, rather than detaching us from and lifting us above it. As the creation of humanity as man and woman in the image of God displays, human freedom, 'can be defined in simply no other way than in terms of the existence of human beings over-against-one-another, with-oneanother, and in-dependence-upon-one-another [nicht anders zu bestimmen als in dem Gegenüber-Miteinander-Aufeinander-angewiesen-sein der Menschen]. ${ }^{\prime 36}$

It is in his discussion of the Genesis command to have dominion (1:26) that Bonhoeffer approaches the main themes in Rosenzweig's account of undeadening as well as Paul's account of how it is through renewed practices that we receive the imago dei. When God commands the first pair to 'rule over' creation the freedom of humans for other persons is distinguished from their captivity to the immanent laws of creaturely reality. Not being determined by the laws of the natural world, and so being free from them, is not the same as asserting that humans are liberated from all responsibility to the rest of creation. To be commanded so to rule is to be tasked with owning my place, Bonhoeffer proposes, to receive the materiality through which my life is nurtured and sustained as a work of divine solicitude. But how such holy receiving might proceed is opaque to us in our post-lapsarian world;

We too think that we rule, but the same applies here as on Walpurgis Night: we think we are the one making the move, whereas instead we are being moved. We do not rule; instead we are ruled. The thing, the world, rules humankind; humankind is a prisoner, a slave, of the world, and its dominion is an illusion. Technology is the power with which the earth seizes hold of humankind and masters it. And because we no longer rule, we lose the ground [Boden] so that the earth no longer remains our earth, and we become estranged from the earth. The reason why we fail to rule, however, is because we do not know the world as God's creation and do not accept the dominion we have as God-given but seize hold of it for ourselves. There is no 'being-free-from' without a 'being-free-for'. There is no dominion without serving

\footnotetext{
${ }^{36}$ Bonhoeffer, Creation and Fall, p. 64.
} 
God; in losing the one humankind necessarily loses the other. Without God, without their brothers and sisters, human beings lose the earth. ${ }^{37}$

The two trees in the garden were created perpetually to remind the first couple that God is both the boundary and limit of the creaturely domain. The wonder of the two trees is that the limit of the whole is in them held tangibly before them at the center of their existence. Their limit is that they cannot remain creatures without living in a temporally extended give and take with God. God reminds them of this by setting a boundary, 'Thou shalt not eat'. The trees, whose significance is thus established by the divine command attached to them, address Adam and Eve from beyond creation and in so doing they offer them all that they need to retain their true freedom, that is, that freedom which is exercised in awareness of their place in time and space with God and other creatures. ${ }^{38}$ The trees protect the freedom of human beings which is imperiled by moving from the heart of wonder to 'defining its essence' or 'looking for its boundaries' and it is the reification of God and the hankering to take over the role of moral arbiter that are the first couple's defection from relation with God and precipitate the Fall. ${ }^{39}$ Thus the giving of the tree and the articulate divine prohibition of eating from it must be understood as God's act of love which will sustain the first couple, and allow them to exercise true freedom, as long as they receive it as grace. ${ }^{40}$ As God promises in the command, to defect from it is to die, which is to lose the life-giving

\footnotetext{
${ }^{37}$ Bonhoeffer, Creation and Fall, pp. 66-67. Compare Rosenzweig's emphasis on the same triad, God, Human, World, with the divine speaking as their point of unity. "The world is something. That is to say, it is not nothing; neither is it everything. There are other entities. This preliminary knowledge presupposes that the other entities, namely God and I, are at every moment accessible to the world, reach the world. Mention of the world requires the very next instant mention of man and God. The world is something only because it enters the stream to which it and everything else belongs. It is drawn into the stream by something which is not a part of the world, yet does not claim to be its "essence." The world clings to this something in a purely external manner, indicating thereby that there is something which may be considered outside the world. God and man are truly external to the world, not its interior, nor "essence." By saying that the world is something, we merely express the fact that it is neither man nor God, that neither constitutes its "essence." Thus at last we discover something which is the companion of everything, including every event which takes place in the world, and yet is external to them all: the Word. Language is not the world, nor does it make such claims. What actually is it? Unlike "thought," language cannot presume to be the "essence" of the world. If the world is something which permits the existence of other things exterior to the world but not its essence, there is only one thing that language can be; it must be a bridge between the world and these other things." Franz Rosenzwieg, Understanding the Sick and the Healthy: A View of World, Man and God, Nahum Glatzer trans. and ed. (Cambridge: Harvard University Press, 1999), pp. 70-71.

${ }^{38}$ Bonhoeffer, Creation and Fall, p. 85.

${ }^{39}$ Bonhoeffer, Creation and Fall, "The Pious Question" and *bon Ethics pp. 381-386 on falling into the search for the outer boundary.

${ }^{40}$ Bonhoeffer, Creation and Fall, p. 87.
} 
configuration of immanence and transcendence which persists as long as their freedom is exercised in order to live in responsiveness to the acts of their Creator.

In reaching out for the fruit of the tree of Good and Evil the first couple thus embrace an animated deadness, which is to be condemned to the empty but binding laws of nature and history understood as the circulation of beings. They are dead because in repudiating the history of acts and responses which forms a temporally elaborated life with God, they are left only with their 'bare' lives and the immanent laws that govern it. ${ }^{41}$ This is the purgatorial result of refusing to embrace their bodiliness as created to preserve and orient them in their freedom to be with others. The sheer discreetness of the mass of organic substance of which they are comprised was divinely given to play a constitutive role in serving and shaping relationship. Had they not defected from the word that holds God, creation and humankind together, 'this very revelation of the limit in bodily form, in the love he has for the other person, would have brought Adam an ever deeper knowledge of the grace of the Creator. ${ }^{42}$ But to reject God's word over bodies is to lose them as well, or at least to lose them as a way of negotiating the nearly infinite and multifaceted relations in which human being stand-which is in effect to leave them alone with their own material bodies. They are therefore condemned to make something of the limits of their naked biology, and, having repudiated God's presence, as they do so they have no other horizon for their imagination than earthly things and the circulation of the world's descriptions of these things, the transmission of which Santner has helpfully named 'symbolic investiture'. Thus in repudiating this divinely spoken inner limit the first humans have given up their creatureliness because, by aspiring to transcend immanent contingency they have been utterly subsumed in it. ${ }^{43}$ This is the condition of those who wanted to be like God, who enact what Bonhoeffer calls a living death in their 'not-wanting-to-be-a-creature [NichtGeschöpf-sein-wollen]'44

God has not been content to leave creatures in this estranged and fragmented state, however. The subjective ' $\mathrm{l}$ ' who has been severed from God and is in need of the Creator's

\footnotetext{
${ }^{41}$ Bonhoeffer, Creation and Fall, p. 91.

42 Bonhoeffer, Creation and Fall, p. 118.

${ }^{43}$ Bonhoeffer, Creation and Fall, p. 115. "The thing about Susan is that she's making the leap into selfreconstruction so late in life. Her new dominant attitude comes from a genuine need, but it's so twisted by years of-I don't know exactly what." Microserfs, p. 245.

${ }^{44}$ Bonhoeffer, Creation and Fall, p. 116.
} 
life giving address is not left bereft, because all humanity has been addressed 'in Jesus Christ, in the cross, in the church. ${ }^{45}$ This is a freeing address in which, paralleling the events of the first creation, the Creator enters the creation tangibly in person and on a tree. In Jesus Christ this address engages the public domain of generic symbolic systems by incorporating human beings to whom Jesus Christ has been bound-first in the church and then with neighbors of all sorts. This is why Bonhoeffer can so bluntly assert that there is no way back to the earth except via God and our brothers and sisters. ${ }^{46}$ It is because we are bodily creatures that we are related to the whole created world and to other bodies: we are dependent on other creatures and they are on us. As Santner has stressed, however, to admit this can be paralyzing if it is nothing more than a recognition that we exist within an almost infinite matrix of relations to which we are bound by a range of moral laws.

We were not created to be simply bodies in such nearly-infinite relations with other discreet created bodies and forces, Bonhoeffer insists. As the second creation account stresses, humans beings live preeminently by God's Spirit, and it is the working of this Spirit which is the essence of human undeadness. When we were dead in sin, trapped in life that is unfree in the routines of the laws of nature and history, Jesus Christ has come to us and resurrected us through his Spirit.

That is why where the original body in its created being has been destroyed, God enters it anew in Jesus Christ, and then, where this body too is broken, enters the forms of the sacrament of the body and blood. The body and blood of the Lord's Supper are the new realities of creation promised to fallen Adam. Because Adam is created as body, Adam is also redeemed as body [and God comes to Adam as body], in Jesus Christ and in the sacrament. ${ }^{47}$

It is the bodiliness of the offer of true freedom to human beings through the incarnation and cross, through the sacraments and through the neighbor, that we come to understand the mechanisms of the divine work of freeing humans so that they can image God; to return to the responsive life with an acting God who loves and can be loved in return without compulsion.

\footnotetext{
${ }^{45}$ Bonhoeffer, Creation and Fall, pp. 116-117.

${ }^{46}$ Bonhoeffer, Creation and Fall, p. 67.

${ }^{47}$ Bonhoeffer, Creation and Fall, p. 79.
} 
Human beings suffering their redemption, as Bonhoeffer understands them, are beings who are learning what it means to image God amidst their shame before others, a shame that enflames hate and the desire to dominate, forms of an 'extreme lack of respect for thingsas-they-are [Unsachlichkeit] ${ }^{\prime}{ }^{48}$ It is because Jesus Christ is above these relations of living deadness, Bonhoeffer later explains, ${ }^{49}$ that he can and must enter into them, entering the relations between creatures in order to break in on our manias and so to reshape our behavior by showing us that the sheer and fallen 'thereness' of the creaturely neighbor is good. Only thus are we freed to receive her or him with gratitude because offering us precious purchase on creation. ${ }^{50}$ What God has done in Jesus Christ for all, and once for all, enters our lives and remakes our practices of relating to others by personally confronting our projections onto others (which, as Santner and Coupland have emphasized, is inevitably in the idiom of the universal).

Self-centered love constructs its own image of other persons, about what they are and what they should become. It takes the life of the other person into its own hands. Spiritual love recognizes the true image of the other person as seen from the perspective of Jesus Christ. It is the image Jesus Christ has formed and wants to form in all people. ${ }^{51}$

To confess the Christian God as Creator means then, concretely, that we are liberated not to transcend creation, but to receive our being in Christ (from the Father's right hand) by learning what it means to be a creature, that is, to recognize and freely embrace loving relations with other persons as and where they are, with all their brokenness and angularity and as we simultaneously face and repent of our brokenness and shape which is yet another barrier to receiving them. It is receiving another creature in this way which is to image God's love through Jesus Christ. This receiving must constantly distinguish between our appreciation of the creaturely and personally edifying aspects of our relation with other persons and their truth in Jesus Christ as the gift, presence and work of God. Only thus do we discover our redeemed self that is hidden in Christ.

\footnotetext{
${ }^{48}$ Bonhoeffer, Creation and Fall, p. 123.

49 "Self-centred, emotional love can never comprehend spiritual love, for spiritual love is from above." Bonhoeffer, Life Together, p. 43.

${ }^{50}$ Dietrich Bonhoeffer, Life Together, DBWE 5, Geoffrey Kelly ed., Daniel Bloesch and James Burtness trans. (Minneapolis: Fortress, 1996), pp. 43-47.

${ }^{51}$ Bonhoeffer, Life Together, p. 44.
} 


\section{Conclusion: the everyday as site of the divine call}

There are many points of overlap between Santner's account of Rosenzweig and Bonhoeffer's account of creation in Creation and Fall: on the articulacy and centrality of God's speaking for theology and ethics; a positive view of the connection of this living speech with command/Torah/law; concern with daily life; the critique of generic/generalized ontologies in favor of an ontology of interpersonal encounter; an antimodern account of freedom as freedom-for-loving-relationship based on God's prior election and rescue; on the problem of contemporary entrapment as a futile quest to delimit the margins rather than to discover life and wonder at the center of everyday life; and on diagnoses such as that the Hegelian account of history and the casting of God-talk in the third person rather than as a hearing from and speaking to God provide the conceptual scaffolding within which many of these problems can be profitably addressed.

That said, it is also important to notice, first, that Rosenzweig's work helpfully clarifies why it is important to affirm that it is to our sinful self that God's address comes. The condescending love for us of Christ Jesus speaks to us as fallen creatures, not just to our 'ideal' and therefore generic selves, the idea (read perfected) aspects of our personality. No genuine embrace of ourselves, other people or any other places or beings can occur apart from this acknowledgement of the reality of sin, and any resistance to this realization will estrange us from given creatures.

Second, Rosenzweig's position elaborates Bonhoeffer's much more suggestive but not elaborated insistence that Jesus Christ enters the center of life in order to renew it. In reading Jesus Christ as the giver of the wonder drawing us into creaturely life a wider range of human experiences become comprehensible as the means of Jesus' Christ's appearing and claiming us for a life lived 'in the heart of wonder'. Rosenzweig thus offers us a sympathetic way to fill out Bonhoeffer's allusion to the Christian's receiving of their life that is hidden in Jesus Christ. We must learn to receive the wonder of life, and the calling of our names by other human beings in love, as the articulate claim of Jesus Christ who is claiming us by name and in this way rendering us creatures.

Finally, Rosenzweig's thought suggests why Bonhoeffer's treatment in Creation and Fall, with its emphasis on God's address in Jesus Christ's cross and church needs the supplement 
that he later develops. In order for the particularity of the divine work of 'undeadening' to be preserved the stepping of Jesus Christ in the Spirit between human beings in order to reveal them in their broken particularity as lovable must be understood as God's own articulate act, to be received as an invitation into a richer temporally extended life of transformative exchange with both my neighbor and the God who gifts me to myself through them. We are not only called to life generally in cross, ecclesia and tangible sacrament which would be to enter it as a law, another 'relation' to be acceded to. What brings it to life as an event of interpersonal love is the messianic inbreaking that unexpectedly enters our everyday lives - to render them truly creaturely. We will not, on our own, escape being 'mobile lovers' because we are born into a fallen world demonically held together by the webs of a roving desire that ruthlessly isolates us. But we can pray 'Thy kingdom come'-which is to open ourselves to the joyous pain of being opened to those over whose shoulders we compulsively gaze. 